\title{
Late Pleistocene-Holocene geochemical history inferred from Lake Tecocomulco sediments, Basin of Mexico, Mexico
}

\author{
P. D. Roy, ${ }^{1 *}$ M. CABAllero, ${ }^{2}$ R. LOZANO,${ }^{1}$ T. $\mathrm{PI}^{1}$ and O. MORTON ${ }^{2}$ \\ ${ }^{1}$ Departamento de Geoquímica, Instituto de Geología, Universidad Nacional Autónoma de México, \\ Ciudad Universitaria, 04510, México D.F., México \\ ${ }^{2}$ Instituto de Geofísica, Universidad Nacional Autónoma de México, Ciudad Universitaria, 04510, México D.F., México
}

(Received April 23, 2008; Accepted September 15, 2008)

\begin{abstract}
This paper presents stratigraphy, mineralogy, multi-element geochemistry, organic and inorganic carbon contents in the sediments along a $255 \mathrm{~cm}$ long depth profile from Lake Tecocomulco in the north-eastern part of the Basin of Mexico. Mineralogical abundance, elemental ratios, chemical index of alteration (CIA), abundance of $\mathrm{CO}_{3}$ and $\mathrm{C}_{\text {org }}$ divide the depth profile into geochemical zones and provide insight to the volcanic eruptions and phases of different paleohydrological events during the last $31,000{ }^{14} \mathrm{C}$ yr BP. The dacite to rhyolite air fall tephra pre-date the LGM $\left(\mathrm{ca} .31,000{ }^{14} \mathrm{C} \mathrm{yr} \mathrm{BP}\right)$ and might be from a Plinian eruption event at the Tláloc volcano located at $60 \mathrm{~km}$ in the south-west of the lake. The lake sediments are characterized by higher CIA values and metal contents between $c a$. 30,000-29,000 ${ }^{14} \mathrm{C}$ yr BP. Between $c a$. $28,000-25,700{ }^{14} \mathrm{C}$ yr BP, sediments have lower CIA values and contain easily weatherable amphiboles. Abundant calcite and low CIA suggest arid conditions during $c a .25,700$ and $c a .16,300{ }^{14} \mathrm{C} \mathrm{yr} \mathrm{BP}$, respectively. Between $c a$. 16,300 and $3,300{ }^{14} \mathrm{C}$ yr BP, the sediments show lower CIA and sediments of the last $c a .3,300{ }^{14} \mathrm{C}$ yr BP show highest CIA, $\mathrm{C}_{\text {org }}$ and higher metal contents. Given the regional nature of this record, we interpret the geochemical history at Lake Tecocomulco in terms of variable precipitation, inflow and aeolian activity.
\end{abstract}

Keywords: Late Quaternary, geochemistry, paleohydrology, Lake Tecocomulco, Basin of Mexico

\section{INTRODUCTION}

Endorreic continental lake basins located near climatic boundaries have been recognized as potential registers of paleoclimatic records (Metcalfe, 1997; Lozano-García and Ortega-Guerrero, 1998; Enzel et al., 1999; Schuett, 2000; Sinha et al., 2006; Roy et al., 2006) as small changes in the climatic system may result in major changes in the geomorphological processes in the lake catchment (i.e., erosion, runoff, aeolian activity etc.), fluctuations in lake levels and sediments deposited within. Depending upon the composition of catchment lithologies, the inflowing water transports clastic minerals and soluble ions into the endorreic basins. Subsequently, the precipitation of authigenic evaporite minerals occurs with increasing water salinity and varying precipitation gradient of the salts due to both climatic and hydrological factors (Hardie et al., 1978; Rosen, 1994). Geochemical indicators of catchment erosion and soil formation, sediment influx into the lake basin, chemical weathering of the clastic minerals and varying salinity and evaporation

*Corresponding author (e-mail: p_debajyotiroy@yahoo.com) Copyright $@ 2009$ by The Geochemical Society of Japan. have been used as proxies to infer the paleohydrological and paleolimnological conditions of late Quaternary lakes (e.g., Ebro Basin, Spain, Schuett, 1998, 2000; Thar Desert playa lakes, India, Enzel et al., 1999; Roy et al., 2006, 2008; Sinha et al., 2006 etc.).

In Mexico, an east-west series of high altitude endorreic basins are present along the Trans-Mexican Volcanic Belt (TMVB). These high altitude basins are located near the border between the arid climates characteristics of Northern Mexico, under the influence of the Subtropical High Pressure Cells, and the temperatetropical climates which dominate central and southern Mexico and which are controlled mainly by the seasonal migration of the Intertropical Convergence Zone and the easterly trade winds which bring humidity from the Gulf of Mexico and Caribbean Sea to the region (MosiñoAleman and García, 1974; Douglas et al., 1993). The basin of Mexico is one of the most extensively studied of these basins given its long lacustrine record and its long history of human occupation, currently represented by the extensive urban area of Mexico City. The basin hosts a number of relict lacustrine sub-basins: Xochimilco and Chalco in the south, Texcoco in the centre, Zumpango and Xaltocan in the north and Tecocomulco and Tochac in the north-east (Fig. 1). Previous paleohydrological and 


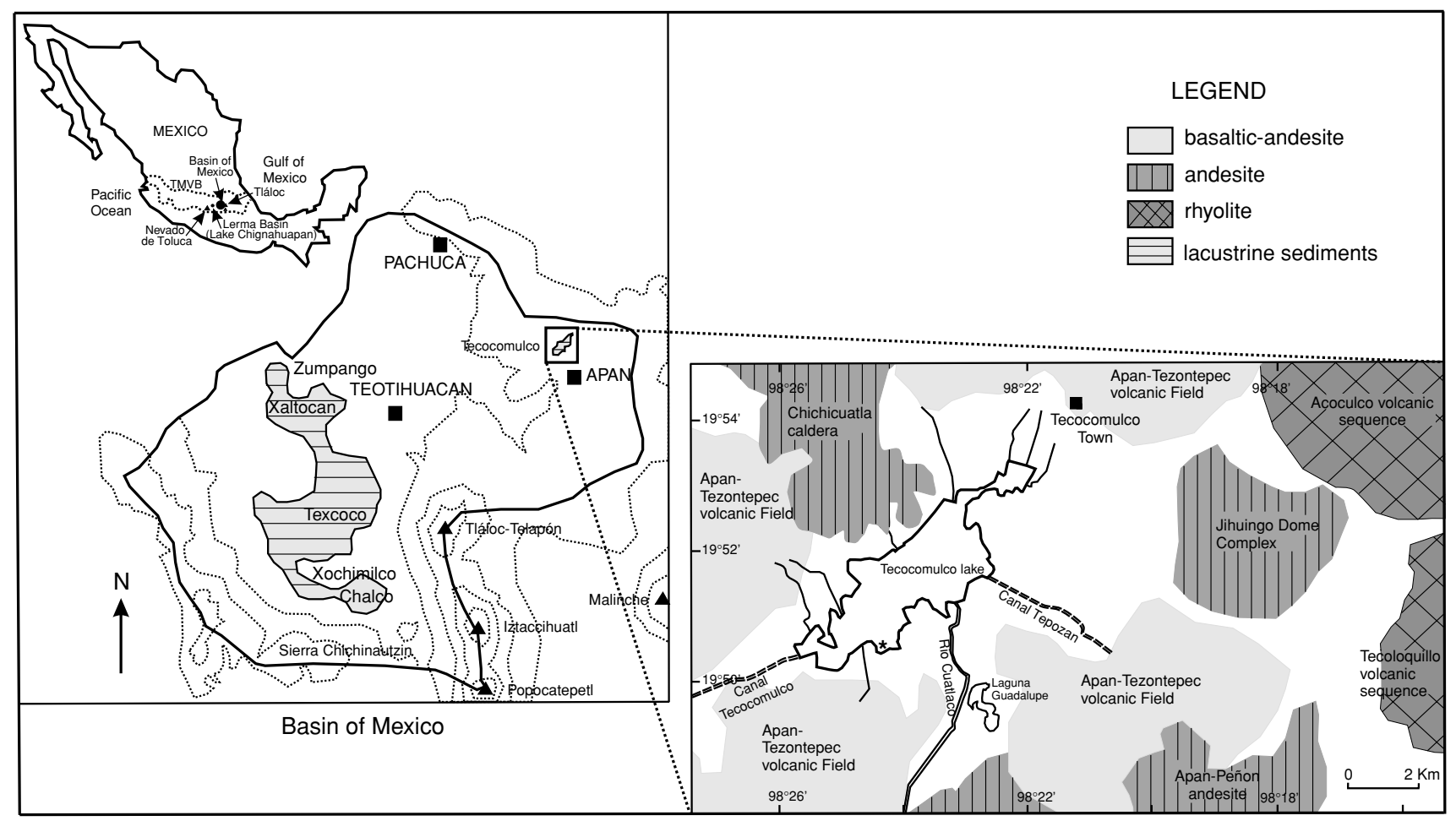

Fig. 1. Location map of the Basin of Mexico, showing Lake Tecocomulco and its surroundings. The sampling location is marked (*).

paleolimnological studies have been undertaken in the sedimentary records from lakes Chalco, Texcoco, and Tecocomulco (Bradbury, 1971, 1989; Lozano-García et al., 1993; Caballero, 1997; Caballero and OrtegaGuerrero, 1998; Lozano-García and Ortega-Guerrero, 1998; Caballero et al., 1999) using both biological and physical proxies (i.e., diatoms, pollen, spores and magnetic susceptibility). The lake level fluctuations and changes in plant communities, constrained by tephrochronology and radiocarbon ages, have been related to climatic conditions during the Late Pleistocene (MIS 3 and 2) and Holocene (MIS 1). The results of these works indicate that during MIS 3 ( $c a .50,000-30,000{ }^{14} \mathrm{C}$ yr BP) lakes Chalco and Tecocomulco were deeper than during the last glacial maximum or at present and the pollen data from Tecocomulco suggest a relatively dense forest cover. A trend towards reduction in lake levels is observed after ca. 30,000 ${ }^{14} \mathrm{C}$ yr BP in Chalco and Tecocomulco, with pollen data from Texcoco and Chalco indicating more extensive grasslands and the presence of open woodlands which are associated to drier and colder climates at the beginning of the last glacial, between $25,000-15,000{ }^{14} \mathrm{C}$ yr BP (early MIS 2). Only Lake Chalco shows an increase in lake level at $c a .22,000{ }^{14} \mathrm{C}$ yr BP, but this is interpreted as a modification of the hydrological setting after particularly intense volcanic activity (Caballero and
Ortega-Guerrero, 1998). By the end of the last glaciation (late MIS 2, ca. $15,000-10,000{ }^{14} \mathrm{C}$ yr BP) the pollen data from Chalco suggest an increase in temperature with a decrease in the grasslands, the presence of denser forests and a stable to slightly higher water level. However, records from the Texcoco and Tecocomulco sub-basins show an important hiatus over the late Pleistocene to Holocene transition (ca. 14,000 to $5,000{ }^{14} \mathrm{C}$ yr BP). In Chalco, the early Holocene ( $\mathrm{ca} .10,000$ to $5,000{ }^{14} \mathrm{C} \mathrm{yr}$ $\mathrm{BP}$ ) is a time of low lake levels but with dense vegetation cover, however this interval is part of the sediment hiatus present in the other records. The records from the three lakes suggest an increase in water level by the late Holocene $\left(<c a .5,000{ }^{14} \mathrm{C}\right.$ yr BP).

The records from Tecocomulco, Texcoco and Chalco, however, show some limitations that hinder palaeoclimatic reconstructions. In Tecocomulco, poor pollen and diatom preservation in the sedimentary sequence characterizes the last $25,000{ }^{14} \mathrm{C}$ yr BP, with an important hiatus at the late Pleistocene to Holocene transitions ( $c a .15,000$ to $3,270{ }^{14} \mathrm{C}$ yr BP). Texcoco shows fragmented pollen and diatom records and also has an important hiatus at the late Pleistocene to Holocene transition (ca. $14,500-6,000{ }^{14} \mathrm{C}$ yr BP). Chalco seems to have the best sedimentary record of the three lakes, but being close to the main volcanic areas in the basin (Popocatepetl 
volcano and Chichinautzin monogenetic volcanic field) volcanic disturbance is important. Given the nature of the data, paleohidrological reconstructions for the basin is incomplete, mostly for the north-eastern part of the basin during and since the last glacial maximum (Caballero et $a l ., 1999)$. This has limited the comparison of records from northern and southern parts of the Basin of Mexico and comprehension of the nature of environmental change in the area during the last glacial maximum (MIS 2, 25,000 to $10,000{ }^{14} \mathrm{C}$ yr BP) to Holocene (MIS $1,10,000{ }^{14} \mathrm{C} \mathrm{yr}$ $\mathrm{BP}$ to present) transition.

In this study, we present sediment stratigraphy and geochemical data including mineralogy, major and trace element geochemistry, elemental ratios, chemical index of alteration (CIA), $\mathrm{C}_{\text {org }}$ and $\mathrm{CO}_{3}$ contents along a 255 $\mathrm{cm}$ sediment profile from the southern margin of the Lake Tecocomulco, with the objectives of understanding the geochemical processes and improving the paleohydrological information during the late Pleistocene and Holocene from the north-eastern part of the basin of Mexico.

\section{Regional Setting}

The basin of Mexico is characterized by temperate climate with precipitation concentrated mainly during the summer months (May to October). Due to topography, the climate of the basin grades from semi-arid in the northeast to sub-humid in the south-west. The north-eastern plains, where Lake Tecocomulco lies, are located at a higher altitude $(c a .2450 \mathrm{~m})$ and receive an average annual precipitation of $600-700 \mathrm{~mm}$. The central part of the basin, where the relicts of Lake Texcoco are present, is situated at a lower elevation and has a relatively drier climate (ca. 400-600 mm/a). The southern plains, where the remnants of Lake Chalco are located, lie at an altitude of $c a .2240 \mathrm{~m}$ and have a relatively moister climate with precipitation of 700-1000 mm/a (García, 1966; Cardoso and García, 1982).

Lake Tecocomulco $\left(19^{\circ} 53^{\prime} \mathrm{N}, 98^{\circ} 23^{\prime} \mathrm{W}\right)$ is located in a graben (Fig. 1) formed by tectonic movements along NE-SW and NW-SE lineaments (Alatriste-Vilchis et al., 2005; Huizar-Alvarez et al., 2005). The lake is elongated in the NE-SW direction (ca.8.2 km long) and the width varies between $<1 \mathrm{~km}$ and $4 \mathrm{~km}$. Presently it is very shallow $(1-2 \mathrm{~m})$ and receives an average annual precipitation of ca. $650 \mathrm{~mm}$. Depending upon the annual precipitation, the lake can cover an area up to $27 \mathrm{~km}^{2}$ or can be completely dry. During the summer months, the Cuatlaco river and other smaller rivulets carry rain water and transport sediments from the catchment into the lake basin. Field and laboratory observations during 1992 and 2006 indicate that the lake water has neutral $\mathrm{pH}(6.8-7.1)$ and relatively low electrical conductivity (250-240 $\mu \mathrm{S} / \mathrm{cm})$. Car- bonates $\left(\mathrm{HCO}_{3}{ }^{-}+\mathrm{CO}_{3}{ }^{2-}\right)$, sodium $\left(\mathrm{Na}^{+}\right)$, potassium $\left(\mathrm{K}^{+}\right)$ and calcium $\left(\mathrm{Ca}^{2+}\right)$ are the dominant ions, whereas chloride $\left(\mathrm{Cl}^{-}\right)$and magnesium $\left(\mathrm{Mg}^{2-}\right)$ are present in lower concentrations.

The geology of the catchment (Fig. 1) corresponds to Miocene to Pleistocene volcanic deposits (García-Palomo and Macías, 2000; García-Palomo et al., 2002). The ApanTezontepec volcanic deposits, consisting of basalticandesites, are present in the west, south-west, south-east and north of the lake. The Chichicuatla and Apan-Peñon andesites outcrop to the north and south of the lake, respectively. The Jihuingo andesites are exposed in the east of the lake. In the north-east and east of the lake, exposures of the Acoculco and Tecoloquillo volcanic sequences are present. The Acoculco deposits consist of high $\mathrm{K}$ series rhyolites. The Tecoloquillo central dome and pyroclastic deposits comprise of mainly rhyolites (LópezHernández and Castillo-Hernández, 1997).

\section{Materials ANd Methods}

A $255 \mathrm{~cm}$ long sediment core (T-A95), collected from the southern shore of Lake Tecocomulco (Fig. 1) using a soil sampler, was investigated for sediment stratigraphy and geochemistry. This core lies only a few meters away from cores T-A and T-B previously studied by Caballero et al. (1999). For the determination of mineralogy, major and trace elements, $\mathrm{C}_{\text {org }}$ and $\mathrm{CO}_{3}, 28$ different samples along the depth profile were subjected to oven drying at $40^{\circ} \mathrm{C}$, homogenising and grinding using an agate mortar. Mineralogy was determined on a Philips 1130/96 X-ray diffractometer (XRD) with digital data collection using a $\mathrm{Cu}$ target from $4^{\circ}$ to $70^{\circ}(2 \theta)$ at a speed of $1^{\circ} / \mathrm{min}$ in the bulk powder samples. Minerals were identified from the positions of the peaks and semi-quantified using the integrated intensities of the major peaks.

Major elements were determined in fused discs prepared from the homogenized powdered bulk samples after drying to determine the loss on ignition (LoI) by igniting the samples at $950^{\circ} \mathrm{C}$. The oxides of 10 major elements ( $\mathrm{Si}, \mathrm{Al}, \mathrm{Ti}, \mathrm{Fe}, \mathrm{Ca}, \mathrm{Mg}, \mathrm{Na}, \mathrm{K}, \mathrm{Mn}$ and $\mathrm{P}$ ) were measured in a Siemens SRS 3000 wavelength dispersive $\mathrm{X}$-ray fluorescence (XRF) spectrometer with Rh-anode $\mathrm{X}$ ray tube. Trace elements $(\mathrm{Cu}, \mathrm{Zn}, \mathrm{Rb}, \mathrm{Pb}, \mathrm{Ba}, \mathrm{Ni}, \mathrm{Cr}$, $\mathrm{Th}, \mathrm{Sr}, \mathrm{Zr}$ and $\mathrm{Y}$ ) were measured by XRF analyses of pressed pellets after the methods of Verma et al. (1996) and Lozano and Bernal (2005). The accuracy and precision of the analysis were between $>2 \%$ and $>1.5 \%$ for major elements and between $>9.5 \%$ and $>6 \%$ for trace elements. The amount of total carbon and inorganic carbon was measured in a CM 5014 coulometer. The organic carbon content was calculated by subtracting the inorganic carbon from total carbon. The accuracy and precision of the analysis were $<5 \%$. Additionally, two tephra 


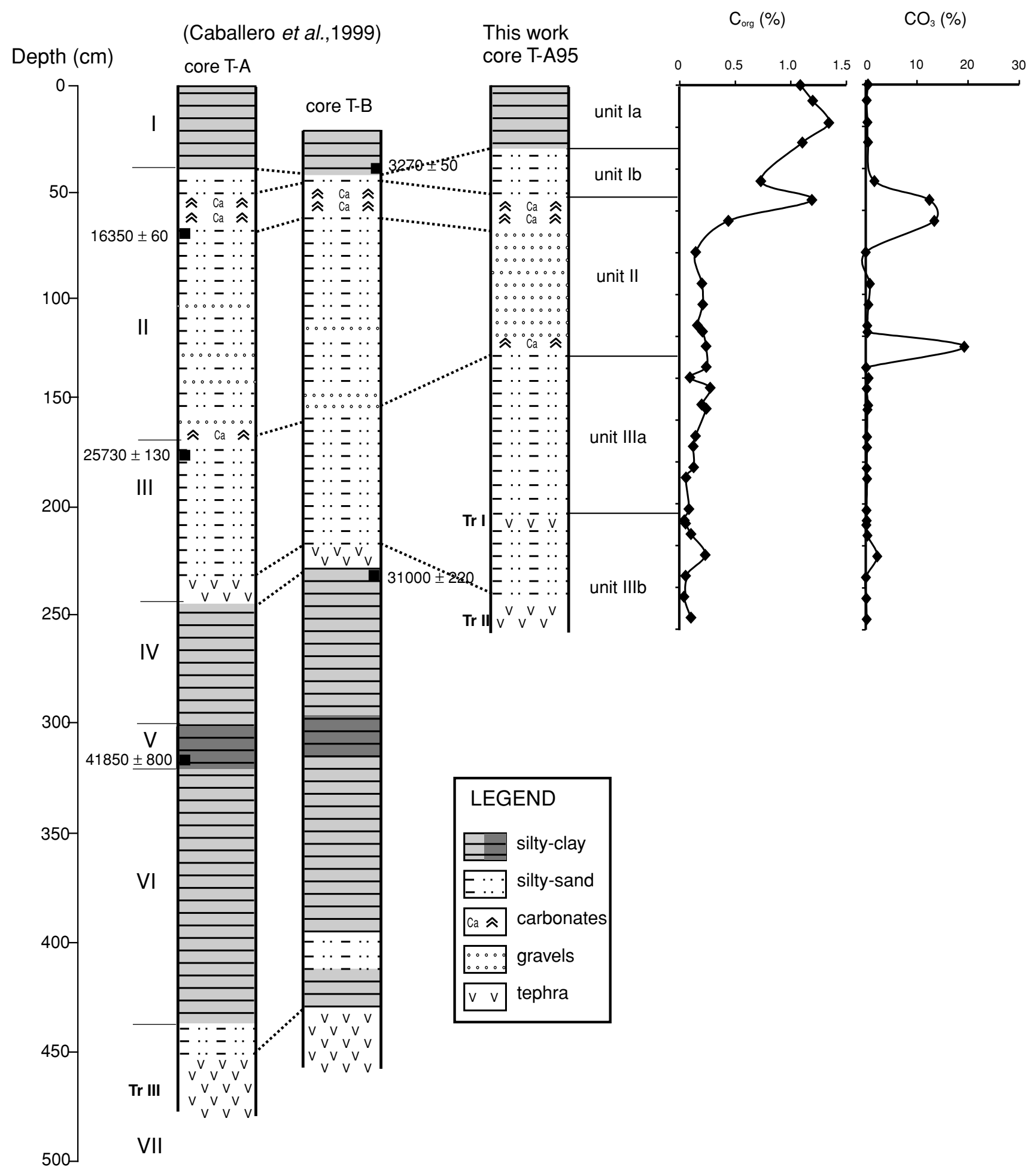

Fig. 2. Stratigraphy of the T-A95 $(255 \mathrm{~cm})$ sediment sequence and distribution of $\mathrm{CO}_{3}$ and $\mathrm{C}_{\text {org }}$ from Lake Tecocomulco and its correlation with the sediment profiles reported by Caballero et al. (1999). 
Table 1. Comparative mineralogy in the stratigraphic units of Lake Tecocomulco (T-A95 core)

\begin{tabular}{|c|c|c|c|c|c|c|c|c|c|c|c|}
\hline Units & $\begin{array}{c}\text { Depth } \\
(\mathrm{cm})\end{array}$ & Quartz & Plagioclases & K-feldspars & $\begin{array}{l}\text { Tridymite/ } \\
\text { Cristobalite }\end{array}$ & Micas & Amphiboles & Halloysite & Iron oxides & Calcite & Amorphous \\
\hline \multirow[t]{4}{*}{$\mathrm{Ia}$} & 0 & +++ & +++++ & & ++ & & & ++ & ++ & & ++ \\
\hline & 7 & +++ & +++++ & & ++ & + & & ++ & ++ & & ++ \\
\hline & 18 & +++ & +++++ & & ++ & & ++ & + & + & & ++ \\
\hline & 27 & ++ & +++++ & & +++ & & + & + & + & & ++ \\
\hline \multirow[t]{2}{*}{$\mathrm{Ib}$} & 35 & ++ & +++++ & & +++ & + & + & & + & & + \\
\hline & 46 & ++++ & ++++ & & ++ & & + & & + & ++ & + \\
\hline \multirow[t]{8}{*}{ II } & 55 & + & +++++ & & ++ & & & & & ++++ & + \\
\hline & 65 & & ++++ & & & & & & & +++++ & + \\
\hline & 75 & ++ & +++++ & & +++ & + & + & + & & & + \\
\hline & 80 & & +++++ & & +++ & & & ++ & + & & ++ \\
\hline & 95 & & +++++ & & ++++- & & & ++ & + & & ++ \\
\hline & 105 & & +++++ & & ++++ & & & + & + & & ++ \\
\hline & 115 & & +++++ & & +++ & & & + & + & & ++ \\
\hline & 125 & & ++ & & ++ & & + & & & +++++ & + \\
\hline \multirow[t]{7}{*}{ IIIa } & 135 & & +++++ & & ++ & & & & & & + \\
\hline & 145 & & ++++ & & ++++ & & ++ & ++ & & & +++ \\
\hline & 155 & & +++++ & & +++ & & + & + & + & & + \\
\hline & 164 & & +++++ & & ++++ & & + & & + & & ++ \\
\hline & 175 & & ++++ & & +++++ & & + & +++ & & & +++ \\
\hline & 185 & & +++++ & & +++++ & & & + & ++ & & ++ \\
\hline & 195 & & +++++ & & +++++ & & & + & + & & ++ \\
\hline \multirow[t]{7}{*}{ IIIb } & 205 & & +++++ & & ++++ & & & ++ & & & +++ \\
\hline & 210 & & ++++ & & +++ & & & & & & ++++ \\
\hline & 215 & & ++++ & & +++++ & & & ++ & + & & +++ \\
\hline & 225 & & +++++ & & ++++ & & & ++ & + & & +++ \\
\hline & 235 & & ++++ & +++ & +++ & & & + & + & & ++ \\
\hline & 245 & +++ & ++ & ++ & ++ & + & + & + & + & & ++ \\
\hline & 255 & +++ & ++++ & ++ & ++ & + & & & + & & + \\
\hline
\end{tabular}

,$+ 1-5 \% ;++, 5-10 \% ;+++, 10-20 \% ;++++, 20-30 \% ;+++++,>30 \%$.

samples of the $c a .31,490{ }^{14} \mathrm{C}$ yr BP eruption from the Tláloc volcano (Rueda et al., 2006) were studied for major elements and two tephra samples from the previously studied T-A and T-B cores (Caballero et al., 1999) representing the $c a .50,000$ and $31,000{ }^{14} \mathrm{C}$ yr BP eruptions (Fig. 2) were studied for both major and trace elements. The major and trace element data of the catchments rocks were taken from García-Palomo et al. (2002).

\section{RESULTS}

Sediment stratigraphy and chronology

The sediment profile of T-A95 core corresponds to the top three stratigraphic units of the T-A and T-B cores studied by Caballero et al. (1999) (Fig. 2). Unit IIIb (255$205 \mathrm{~cm}$ ) consists of alternate laminae of brown and greenish-gray silty-sand in between two different tephra layers. Both the tephra layers are inversely graded and composed of white pumice. The tephra layers are identified here as Tr II $(245-255 \mathrm{~cm})$ and $\operatorname{Tr} I(205-210 \mathrm{~cm})$.
Unit IIIa $(205-130 \mathrm{~cm})$ is composed of dominant light brown silty-sand with minor dark brown silt layers. The overlying unit II $(130-55 \mathrm{~cm})$ has gravels in between two distinct carbonate layers. The carbonate layers (caliche) are present at depths of $60-65 \mathrm{~cm}$ and $125-127 \mathrm{~cm}$. Unit $\mathrm{Ib}(55-30 \mathrm{~cm})$ consists of brown silty-sand and the upper most unit Ia $(30-0 \mathrm{~cm})$ comprises of silty-clay.

Stratigraphic correlation between cores is used to establish the chronology of the T-A95 sequence (Fig. 2). Based on the major and trace element geochemistry, Tr II is correlated to the tephra layer at depths of $240-250 \mathrm{~cm}$ at T-A and $218-222 \mathrm{~cm}$ at T-B. This tephra layer was dated in the T-B sequence to $31,000 \pm 220{ }^{14} \mathrm{C}$ yr BP. The carbonate layers at T-A95 are correlated to the caliche layers at T-A core, the base of the caliche at $170-180 \mathrm{~cm}$ (transition between units III and II) was dated to 25,730 $\pm 130{ }^{14} \mathrm{C}$ yr BP and the caliche at $55-60 \mathrm{~cm}$ at T-A core was dated to $16,350 \pm 60{ }^{14} \mathrm{C}$ yr BP. In core T-B, the base of organic rich unit I in Caballero et al. (1999) was dated to $3270 \pm 50{ }^{14} \mathrm{C}$ yr BP and in T-A95 this date correlates 

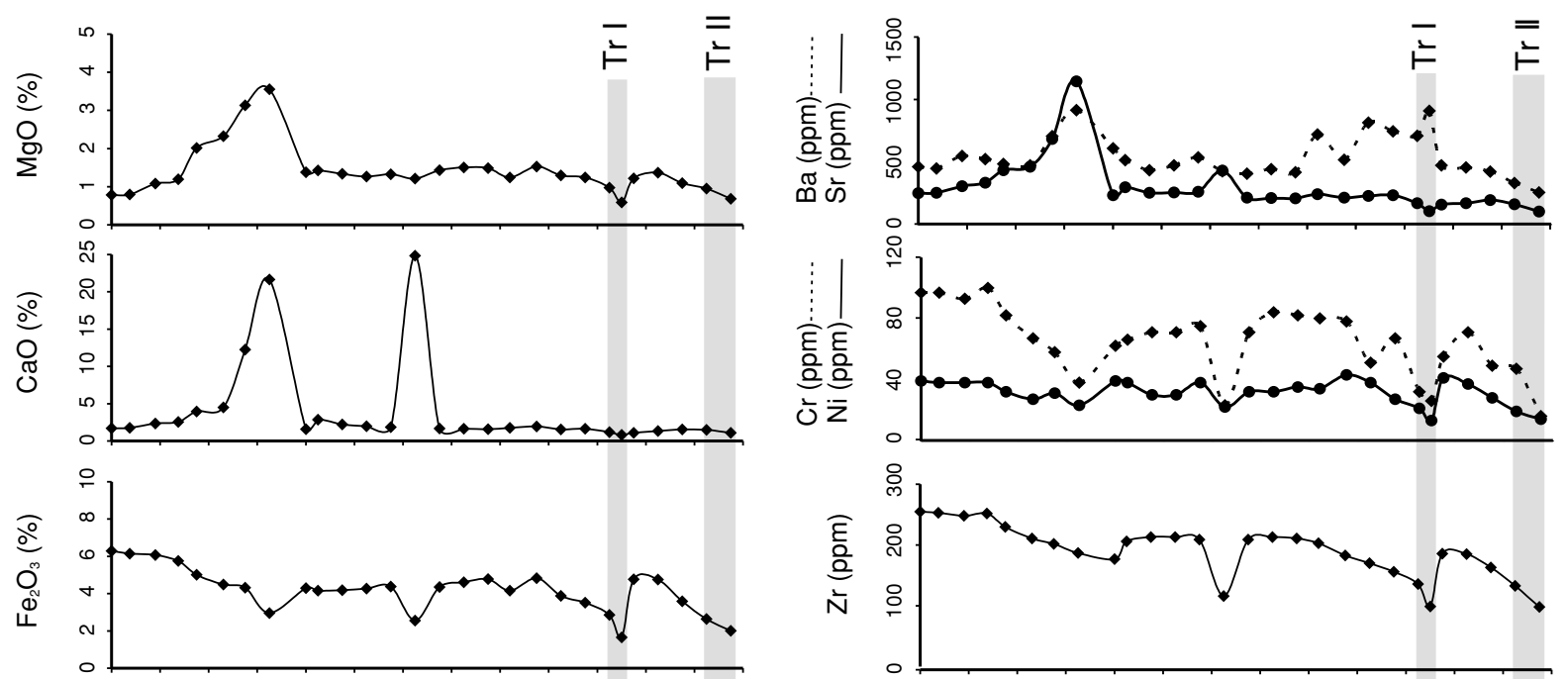

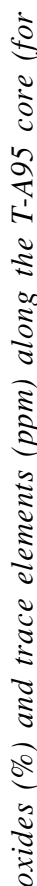
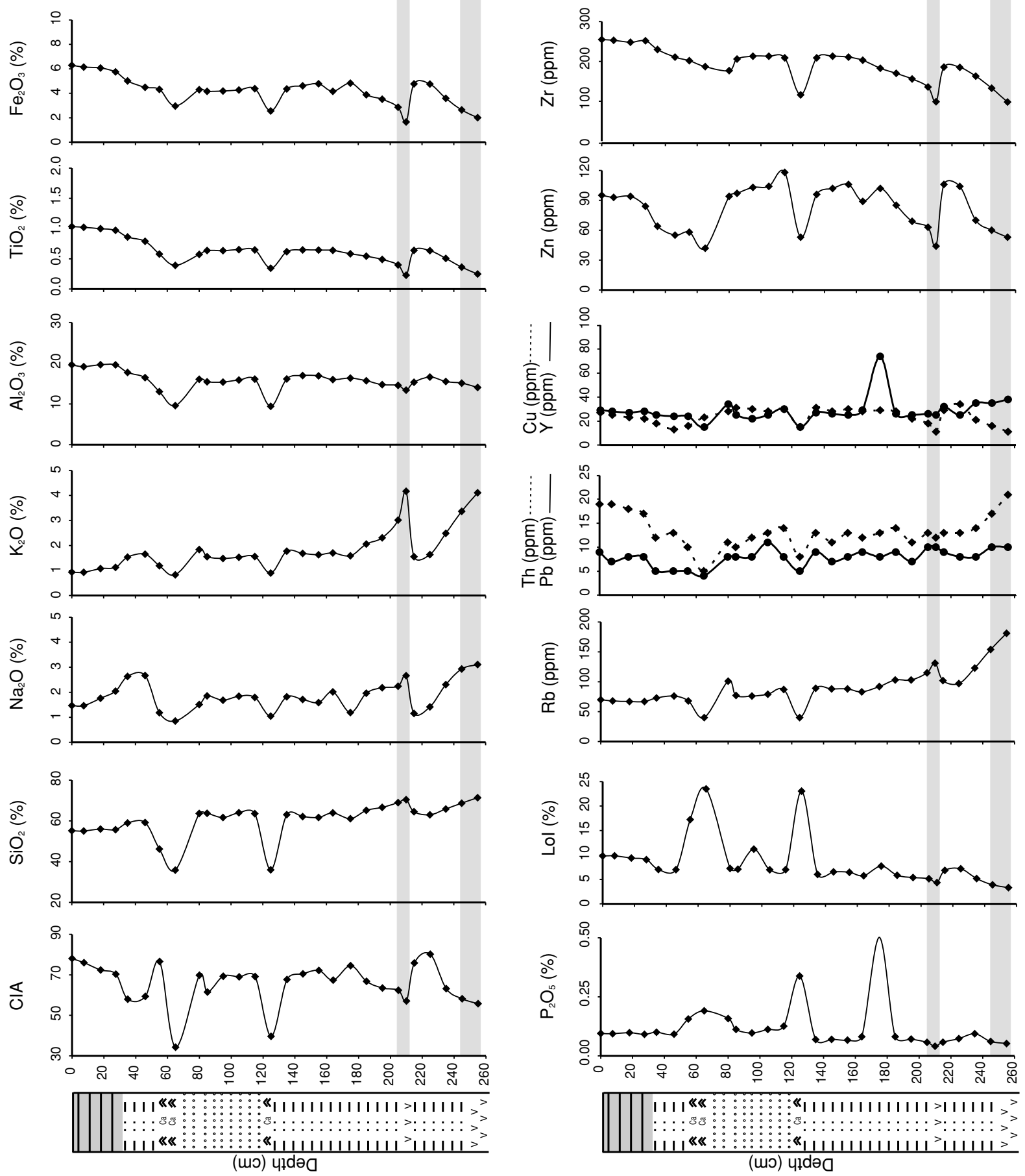
with the base of unit Ia (Fig. 2). Cores T-B and T-A show a sedimentary hiatus between the caliche layer and the base of unit I in Caballero et al. (1999) (ca. 15,000-3270 ${ }^{14} \mathrm{C}$ yr BP). In core T-A95, there is a better representation of this interval, allowing identification of unit Ib overlying the caliche layer, while unit Ia correlates with former unit I. The tephra layer of $c a .50,000{ }^{14} \mathrm{C}$ yr BP (identified here as Tr III) reported by Caballero et al. (1999) in the cores T-A (below $450 \mathrm{~cm}$ ) and T-B (below $420 \mathrm{~cm}$ ) is not seen in the shallower T-A95 sequence and Tr I, present in T-A95, was not reported in the earlier study. Linear interpolation of the ${ }^{14} \mathrm{C}$ ages assigns a maximum age of ca. $29,000{ }^{14} \mathrm{C}$ yr BP for Tr I.

\section{Organic and inorganic carbon}

Figure 2 shows the distribution of organic and inorganic carbon $\left(\mathrm{C}_{\text {org }}\right.$ and $\left.\mathrm{CO}_{3}\right)$ along the depth profile of core T-A95. Organic carbon $\left(\mathrm{C}_{\text {org }}\right)$ content along this sediment sequence varies between 0 and $1.3 \%$. The concentration is relatively higher in the upper part of the sequence (units Ia, Ib and top of unit II). Sediments of units Ia and Ib contain between 0.7 and $1.3 \%$ of $\mathrm{C}_{\text {org }}$ and the upper part of unit II $(55-65 \mathrm{~cm})$ contains between 0.4 and $1.2 \%$ of $\mathrm{C}_{\text {org }}$. In the rest of the sequence, $\mathrm{C}_{\text {org }}$ content varies between 0 and $0.3 \%$. Inorganic carbon $\left(\mathrm{CO}_{3}\right)$ content is variable and mirrors the abundance of calcite: the layers at depths of $60-65 \mathrm{~cm}$ and at $125-127 \mathrm{~cm}$ contain $13.4 \%$ and $19.2 \%$ of $\mathrm{CO}_{3}$, respectively. In the rest of the sequence, $\mathrm{CO}_{3}$ varies between 0 and $1.7 \%$.

\section{Mineralogy}

The sediments of T-A95 core comprise both clastic and non-clastic minerals (Table 1). The assemblage of clastic minerals contains plagioclases, polymorphs of quartz (i.e., tridymite and cristobalite), halloysite and amorphous phases. Few samples along the depth profile contain quartz, K-feldspars, micas, amphiboles and iron oxides (hematite and magnetite). With few exceptions, plagioclases constitute the most abundant detrital mineral (up to 60\%) followed by cristobalite and tridymite (up to $40 \%$ ). The non-clastic calcite is present in the carbonate layers at depths of $60-65 \mathrm{~cm}$ and $125-127 \mathrm{~cm}$.

The tephra layers are characterized by different mineralogical assemblages. Tr I $(205-210 \mathrm{~cm})$ consists of plagioclases and polymorphs of quartz, i.e., tridymite and cristobalite, and similar to the clastic lake sediments. $\mathrm{Tr}$ II $(245-255 \mathrm{~cm})$ has plagioclases, $\mathrm{K}$-feldspars along with minor quartz and its polymorphs. Both micas and amphiboles are present in trace amounts in Tr II. The abundance of both plagioclases and amorphous phases are significantly higher in $\operatorname{Tr}$ I compared to Tr II. Except for Tr II, K-feldspars are not present in the sediment profile. However, quartz is present in the upper part of the sediment sequence (units Ia, Ib and few samples of unit
II). Halloysite (7 $\AA$ ) is present in varying abundances in different horizons, but it shows a higher upward pattern in unit Ia (Table 1).

\section{Major and trace element geochemistry}

Figure 3 shows the distribution of major element oxides and trace elements along the depth profile of T-A95 core. $\mathrm{SiO}_{2}, \mathrm{Na}_{2} \mathrm{O}$ and $\mathrm{K}_{2} \mathrm{O}$ show low values within carbonate layers and high concentrations in the tephras. Both $\mathrm{Tr}$ I and $\mathrm{Tr}$ II contain between $68.7-71.4 \%$ of $\mathrm{SiO}_{2}, 2.2-$ $3.1 \%$ of $\mathrm{Na}_{2} \mathrm{O}, 3.0-4.2 \%$ of $\mathrm{K}_{2} \mathrm{O}$, respectively. In the carbonate layers, $\mathrm{SiO}_{2}, \mathrm{Na}_{2} \mathrm{O}$ and $\mathrm{K}_{2} \mathrm{O}$ values varies between $35.8-35.9 \%, 0.8-1.0 \%, 0.8-0.9 \%$, respectively. The patterns of $\mathrm{Rb}, \mathrm{Pb}$ and $\mathrm{Th}$ are similar to that of $\mathrm{SiO}_{2}, \mathrm{Na}_{2} \mathrm{O}$ and $\mathrm{K}_{2} \mathrm{O}$. The tephra layers contain between $115-181 \mathrm{ppm}$ of Rb, 12-21 ppm of $\mathrm{Pb}$ and $10 \mathrm{ppm}$ of Th. In the carbonate layers, $\mathrm{Rb}, \mathrm{Pb}$ and Th vary between $40 \mathrm{ppm}, 5-8 \mathrm{ppm}$ and 4-5 ppm, respectively. The distributions of $\mathrm{TiO}_{2}$, $\mathrm{Al}_{2} \mathrm{O}_{3}$ and $\mathrm{Fe}_{2} \mathrm{O}_{3}$ show lower concentrations in calcite enriched horizons $\left(\mathrm{TiO}_{2}, 0.3-0.4 \% ; \mathrm{Al}_{2} \mathrm{O}_{3}, 9.4-9.6 \%\right.$; $\left.\mathrm{Fe}_{2} \mathrm{O}_{3}, 2.6-3.0 \%\right)$ as well as in the tephra layers $\left(\mathrm{TiO}_{2}\right.$, $\left.0.2-0.4 \% ; \mathrm{Al}_{2} \mathrm{O}_{3}, 13.4-15.1 \% ; \mathrm{Fe}_{2} \mathrm{O}_{3}, 1.7-2.9 \%\right)$. These oxides are present in higher abundance $\left(\mathrm{TiO}_{2}, 1.0 \%\right.$; $\left.\mathrm{Al}_{2} \mathrm{O}_{3}, 19.2-19.6 \% ; \mathrm{Fe}_{2} \mathrm{O}_{3}, 5.7-6.3 \%\right)$ in the sediments of unit Ia $(0-30 \mathrm{~cm})$ and in intermediate concentrations in the rest of the sequence. The trends of $\mathrm{Cu}, \mathrm{Zn}, \mathrm{Cr}, \mathrm{Ni}$ and $\mathrm{Zr}$ are similar to patterns of $\mathrm{Ti}, \mathrm{Al}$ and $\mathrm{Fe}$ oxides. In the tephra layers, $\mathrm{Cu}, \mathrm{Zn}, \mathrm{Cr}, \mathrm{Ni}$ and $\mathrm{Zr}$ vary between $11-$ 18 ppm, 44-63 ppm, 16-47 ppm, 13-21 ppm and 98-136 ppm, respectively. The carbonate layers contain 15-23 ppm of $\mathrm{Cu}, 42-53 \mathrm{ppm}$ of $\mathrm{Zn}, 23-38 \mathrm{ppm}$ of $\mathrm{Cr}, 22-23$ ppm of $\mathrm{Ni}$ and $116-187 \mathrm{ppm}$ of $\mathrm{Zr}$.

The distribution of $\mathrm{CaO}, \mathrm{MgO}$ and $\mathrm{Sr}$ parallels calcite abundance. The calcite layer at $60-65 \mathrm{~cm}$ shows an enrichment of $\mathrm{CaO}(21.7 \%), \mathrm{MgO}(3.6 \%)$ and $\mathrm{Sr}(1146$ ppm), whereas calcite at $125-127 \mathrm{~cm}$ shows higher abundance of $\mathrm{CaO}(24.8 \%)$ and $\mathrm{Sr}(430 \mathrm{ppm})$. This indicates that the calcite at $60-65 \mathrm{~cm}$ depth is $\mathrm{Mg}$-bearing. The calcite enriched horizons are also characterized by higher values of loss on ignition (LoI) and $\mathrm{P}_{2} \mathrm{O}_{5}$. Additionally, $\mathrm{P}_{2} \mathrm{O}_{5}$ shows a peak at $175 \mathrm{~cm}$ depth $(0.5 \%)$. Y shows lower values in calcite rich horizons but there is also a distinct peak at $175 \mathrm{~cm}(74 \mathrm{ppm})$. Higher concentration of $\mathrm{Ba}$ is present in $\operatorname{Tr} \mathrm{I}(808 \mathrm{ppm})$ and in the calcite rich layer at 60-65 cm (915 ppm).

Table 2 presents the average composition of the tephra layers. Both Tr II and Tr I have comparable major element compositions. In $\mathrm{Tr}$ II, $\mathrm{SiO}_{2}$ varies between 68.7 and $71.4 \%$ and total alkalis $\left(\mathrm{Na}_{2} \mathrm{O}+\mathrm{K}_{2} \mathrm{O}\right)$ between 6.3 and $7.2 \%$. Tr I contains between 69.0 and $70.5 \%$ of $\mathrm{SiO}_{2}$ and between 5.3 and $6.8 \%$ of total alkalis. Both are daciterhyolite in nature (Fig. 4). Nevertheless, there exist some differences: $\operatorname{Tr} \mathrm{I}$ is relatively enriched in Ba compared to Tr II, whereas Tr II has relatively higher abundance of 


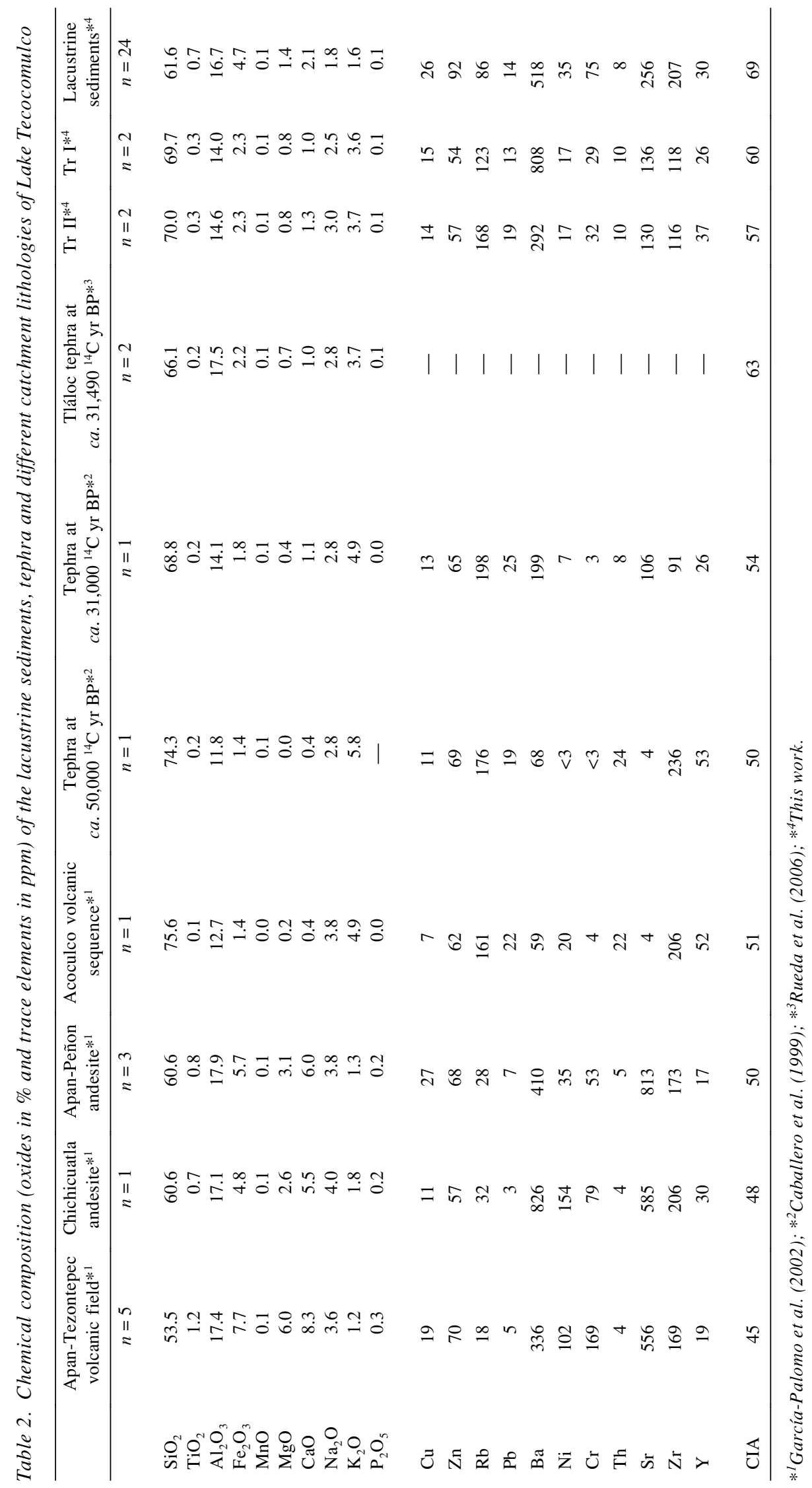




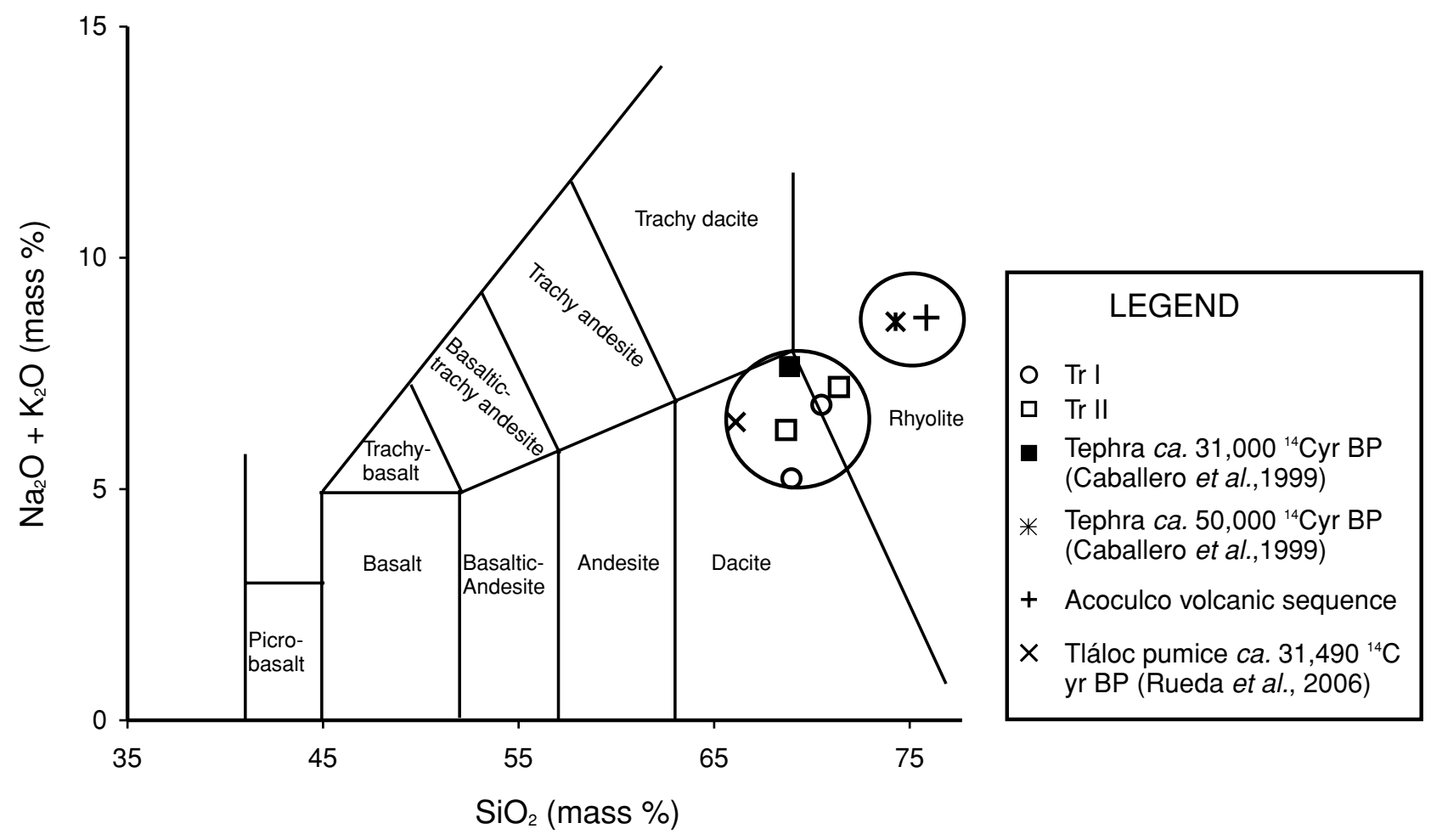

Fig. 4. Classification diagram for the tephra samples after Le Maitre et al. (1989).

$\mathrm{Rb}$ and $\mathrm{Pb}$. The average major element composition of the $c a .31,000{ }^{14} \mathrm{C}$ yr BP tephra layer reported by Caballero et al. (1999) is comparable to both $\mathrm{Tr}$ II and $\mathrm{Tr}$ I with $68.8 \%$ of $\mathrm{SiO}_{2}$ and $7.7 \%$ of total alkalis. However, its trace element abundance shows greater similarity to Tr II. The concentrations of $\mathrm{Rb}$ in both the tephra layers are 198 and $168 \mathrm{ppm}$, respectively and concentrations of $\mathrm{Ba}$ are 199 and 292 ppm, respectively. So we are assigning age of $c a .31,000{ }^{14} \mathrm{C}$ yr BP to the Tr II at T-A95 core. The tephra of $c a .50,000{ }^{14} \mathrm{C}$ yr BP (Tr III) present in both T$\mathrm{A}$ and T-B cores is rhyolite in nature and has higher concentration of $\mathrm{SiO}_{2}(74.3 \%)$ and total alkalis $(8.8 \%)$ compared to both Tr I and Tr II (Fig. 4).

An estimation of the degree of weathering of the siliciclastic sediments along the depth profile at T-A95 core is obtained by calculating the chemical index of alteration (CIA) using the formulae of Nesbitt and Young (1984):

$$
\left.\mathrm{CIA}=\left[\mathrm{Al}_{2} \mathrm{O}_{3} /\left(\mathrm{Al}_{2} \mathrm{O}_{3}+\mathrm{CaO}^{*}+\mathrm{Na}_{2} \mathrm{O}+\mathrm{K}_{2} \mathrm{O}\right)\right] \times 100\right),
$$

where $\mathrm{CaO}$ in the silicate fractions $\left(\mathrm{CaO}^{*}\right)$ was calculated after correcting the $\mathrm{CaO}_{\mathrm{T}}$ for carbonate and phosphate contents (Nesbitt and Young, 1982). Along the depth profile, CIA values vary between 34 and 80 (Fig. 3). The calcite layers at $60-65 \mathrm{~cm}$ and $125-127 \mathrm{~cm}$ have the lowest CIA values (34 and 40) and tephra layers ( $\mathrm{Tr} I$ and $\mathrm{Tr}$
II) have CIA values between 56 and 62 . In the rest of the sequence, CIA values vary between 58 and 80 . Table 2 presents the average major and trace element compositions and CIA values of lacustrine sediments, tephra (this study and Caballero et al. (1999) and Rueda et al. (2006)) and the rocks exposed in the catchments of Lake Tecocomulco (García-Palomo et al., 2002).

\section{Geochemical zones}

Chemical weathering causes degradation of feldspars, mafic minerals and volcanic glass to clay minerals (Nesbitt and Young, 1982). In this process, $\mathrm{Ca}^{2+}, \mathrm{Mg}^{2+}$, $\mathrm{Na}^{+}$and $\mathrm{K}^{+}$are removed and insoluble hydrolysates, i.e., $\mathrm{Al}^{3+}, \mathrm{Si}^{4+}$ and $\mathrm{Ti}^{4+}$, are enriched in the detrital fraction of the sediments (Nesbitt and Young, 1982; Taylor and McLennan, 1985; Sinha et al., 2006). But $\mathrm{K}^{+}$is adsorbed into the clay minerals as it is effective in balancing the net negative charge of the sheet silicates and fits into the hexagonal tetrahedral (Norrish and Pickering, 1983). With gradual evaporation, $\mathrm{Ca}^{2+}$ precipitates as calcite and subsequently as low $\mathrm{Mg}$-calcite. Similarly, $\mathrm{Na}^{+}$combines with $\mathrm{Cl}^{-}$to form halite $(\mathrm{NaCl})$ in highly saline and evaporitic conditions (Hardie et al., 1978; Rosen, 1994; Shaw and Thomas, 1997). The chemical index of alteration (CIA) presents a quantitative estimation of the major element changes in the siliciclastic fractions due to chemical weathering. The fresh rocks and minerals have 


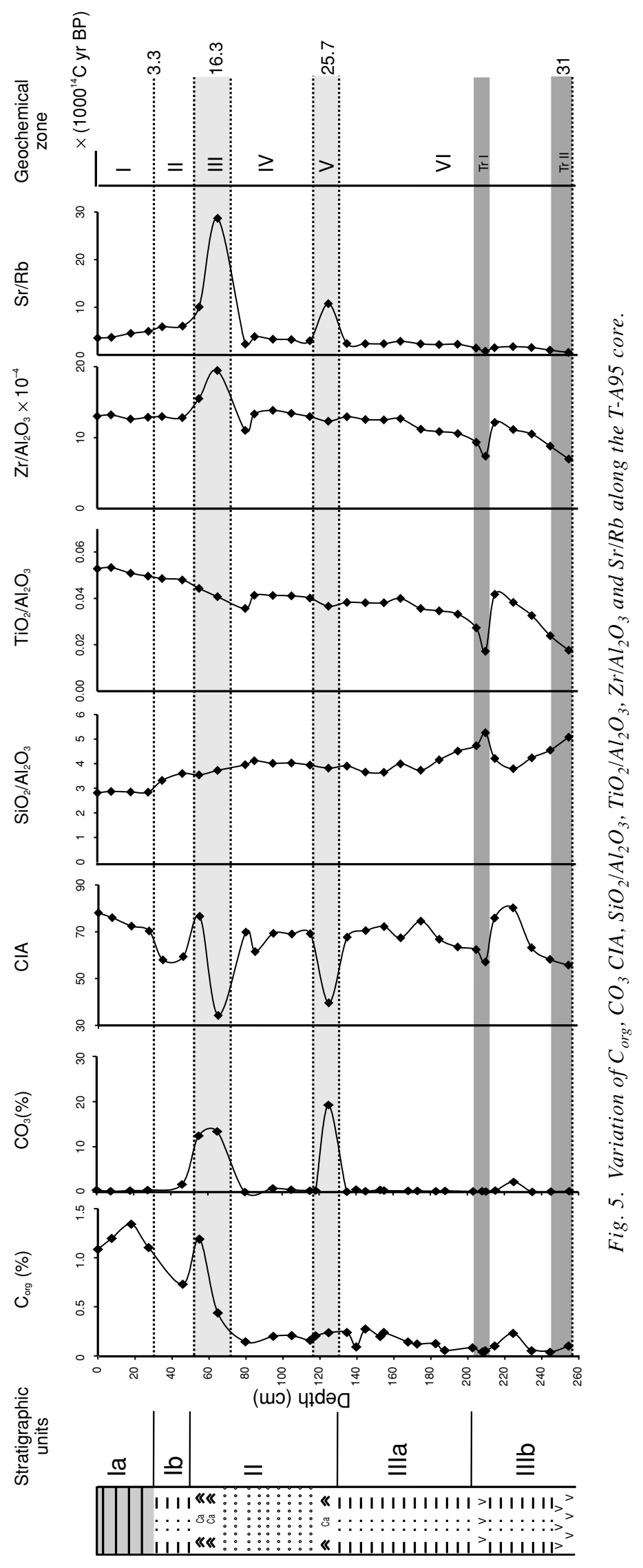


Table 3. Average elemental concentration, $\mathrm{CIA}, \mathrm{C}_{\text {org }}$ and $\mathrm{CO}_{3}$ in the geochemical zones along the depth profile

\begin{tabular}{|c|c|c|c|c|c|c|}
\hline \multirow[t]{2}{*}{ Elements } & \multicolumn{6}{|c|}{ Zones } \\
\hline & $\mathrm{I}(n=4)$ & II $(n=2)$ & III $(n=2)$ & $\mathrm{IV}(n=5)$ & $\mathrm{V}(n=1)$ & $\mathrm{VI}(n=10)$ \\
\hline \multicolumn{7}{|l|}{ Major elements (\%) } \\
\hline $\mathrm{SiO}_{2}$ & 55.48 & 59.10 & 41.02 & 63.33 & 35.95 & 63.71 \\
\hline $\mathrm{TiO}_{2}$ & 1.01 & 0.83 & 0.48 & 0.63 & 0.35 & 0.59 \\
\hline $\mathrm{Al}_{2} \mathrm{O}_{3}$ & 19.50 & 17.11 & 11.33 & 15.77 & 9.42 & 16.02 \\
\hline $\mathrm{Fe}_{2} \mathrm{O}_{3}$ & 6.06 & 4.75 & 3.64 & 4.26 & 2.56 & 4.32 \\
\hline $\mathrm{MnO}$ & 0.10 & 0.08 & 0.06 & 0.09 & 0.11 & 0.06 \\
\hline $\mathrm{MgO}$ & 0.96 & 2.17 & 3.35 & 1.35 & 1.21 & 1.34 \\
\hline $\mathrm{CaO}$ & 2.09 & 4.23 & 16.95 & 2.10 & 24.83 & 1.58 \\
\hline $\mathrm{Na}_{2} \mathrm{O}$ & 1.68 & 2.65 & 1.02 & 1.74 & 1.04 & 1.73 \\
\hline $\mathrm{K}_{2} \mathrm{O}$ & 1.02 & 1.59 & 1.01 & 1.59 & 0.90 & 1.84 \\
\hline $\mathrm{P}_{2} \mathrm{O}_{5}$ & 0.09 & 0.10 & 0.17 & 0.12 & 0.34 & 0.12 \\
\hline \multicolumn{7}{|l|}{ Carbon (\%) } \\
\hline $\mathrm{C}_{\text {org }}$ & 1.18 & 0.96 & 0.44 & 0.18 & 0.24 & 0.13 \\
\hline $\mathrm{CO}_{3}$ & 0.36 & 7.07 & 13.39 & 0.40 & 19.42 & 0.34 \\
\hline \multicolumn{7}{|c|}{ Trace elements (ppm) } \\
\hline $\mathrm{Cu}$ & 24 & 16 & 20 & 29 & 15 & 28 \\
\hline $\mathrm{Zn}$ & 92 & 60 & 50 & 103 & 53 & 93 \\
\hline $\mathrm{Rb}$ & 68 & 75 & 54 & 84 & 40 & 97 \\
\hline $\mathrm{Pb}$ & 18 & 13 & 8 & 12 & 8 & 13 \\
\hline $\mathrm{Ba}$ & 494 & 477 & 811 & 512 & 423 & 506 \\
\hline $\mathrm{Ni}$ & 38 & 30 & 27 & 35 & 22 & 25 \\
\hline $\mathrm{Cr}$ & 97 & 75 & 48 & 69 & 23 & 42 \\
\hline $\mathrm{Th}$ & 8 & 5 & 5 & 9 & 5 & 8 \\
\hline $\mathrm{Sr}$ & 284 & 446 & 915 & 258 & 430 & 205 \\
\hline $\mathrm{Zr}$ & 252 & 221 & 195 & 204 & 116 & 188 \\
\hline $\mathrm{Y}$ & 28 & 25 & 20 & 27 & 15 & 31 \\
\hline \multicolumn{7}{|l|}{ Geochemical ratios } \\
\hline $\mathrm{SiO}_{2} / \mathrm{Al}_{2} \mathrm{O}_{3}$ & 2.85 & 3.46 & 3.64 & 4.02 & 3.82 & 3.99 \\
\hline $\mathrm{Zr} / \mathrm{Al}_{2} \mathrm{O}_{3} \times 10^{-4}$ & 12.93 & 12.89 & 17.47 & 12.92 & 12.32 & 11.71 \\
\hline $\mathrm{TiO}_{2} / \mathrm{Al}_{2} \mathrm{O}_{3}$ & 0.05 & 0.05 & 0.04 & 0.04 & 0.04 & 0.04 \\
\hline $\mathrm{Sr} / \mathrm{Rb}$ & 4.18 & 5.98 & 19.35 & 3.12 & 10.75 & 2.15 \\
\hline CIA & 74 & 59 & 55 & 68 & 40 & 70 \\
\hline
\end{tabular}

CIA values consistently near or below 50. With increasing chemical weathering, CIA values approach 100 (Visser and Young, 1990; Fedo et al., 1995). Higher CIA values indicate higher chemical weathering and reflect deposition in warm and humid conditions and vice versa. During humid phases, inflow into the basin causes higher erosion in the catchments and transports metals into the basin (Schuett, 1998, 2000). Similarly, anoxic conditions in the lake basin lead to preservation of $\mathrm{C}_{\text {org }}$ in the sediments.

In sedimentary environments, $\mathrm{Si}^{4+}$ is associated with quartz and feldspars, whereas $\mathrm{Ti}^{4+}$ is associated with ferromagnesian minerals, e.g., biotite, pyroxenes and amphiboles (Nesbitt, 1979). Similarly, $\mathrm{Zr}^{4+}$ is mainly present in zircon (Taylor and McLennan, 1985). As the absolute concentration of these hydrolysates get diluted due to the higher abundance of calcite and clay minerals, ratios of these elements with respect to $\mathrm{Al}$ is used as indicators of provenance. Higher $\mathrm{TiO}_{2} / \mathrm{Al}_{2} \mathrm{O}_{3}$ ratios explain increasing mafic component to the sedimentary system, whereas higher values of $\mathrm{SiO}_{2} / \mathrm{Al}_{2} \mathrm{O}_{3}$ explain increasing contribution of felsic rocks (Andersson et al., 2004). Similarly, $\mathrm{Zr} / \mathrm{Al}_{2} \mathrm{O}_{3}$ reflects varying abundance of zircon to feldspars. As zircon is concentrated in sandy-silt fractions and can be transported by aeolian process, higher $\mathrm{Zr} / \mathrm{Al}$ can be considered as a proxy for aeolian input (Pye and Krinsley, 1986; Haug et al., 2003; Roy et al., 2006). Further, $\mathrm{Rb}$ is associated with detrital components of the Tecocomulco sediments, whereas $\mathrm{Sr}$ is associated with carbonate. Hence, we consider higher $\mathrm{Sr} / \mathrm{Rb}$ as a proxy for higher evaporation (salinity).

Based on the values of CIA, $\mathrm{C}_{\text {org }}, \mathrm{CO}_{3}$ and geochemical ratios, i.e., $\mathrm{SiO}_{2} / \mathrm{Al}_{2} \mathrm{O}_{3}, \mathrm{TiO}_{2} / \mathrm{Al}_{2} \mathrm{O}_{3}, \mathrm{Zr} /$ $\mathrm{Al}_{2} \mathrm{O}_{3}$ and $\mathrm{Sr} / \mathrm{Rb}$, we divided the sedimentary sequence 
into six (I to VI) geochemical zones (Fig. 5). Table 3 presents the average elemental concentrations, elemental ratios, $\mathrm{CIA}, \mathrm{C}_{\text {org }}$ and $\mathrm{CO}_{3}$ in the geochemical zones. The average elemental concentration of zone VI was calculated without taking the tephra samples into consideration. The elemental ratios in zone VI (ca. 31,000-25,700 ${ }^{14} \mathrm{C}$ yr BP) are comparable to that in zone IV (ca. 25,700$16,300{ }^{14} \mathrm{C}$ yr BP). However, zone VI has relatively lower values of $\mathrm{Zr} / \mathrm{Al}_{2} \mathrm{O}_{3}$ and $\mathrm{Sr} / \mathrm{Rb}$ compared with zone IV. Zone V ( ca. 25,700 ${ }^{14} \mathrm{C}$ yr BP) exhibits higher $\mathrm{CO}_{3}$ and $\mathrm{Sr} / \mathrm{Rb}$, while zone III ( $c a .16,300{ }^{14} \mathrm{C}$ yr BP) shows higher $\mathrm{CO}_{3}, \mathrm{Sr} / \mathrm{Rb}$ and $\mathrm{Zr} / \mathrm{Al}_{2} \mathrm{O}_{3}$. Both zones $\mathrm{V}$ and III show lower trace element abundance. Zone II (16,300-3,300 ${ }^{14} \mathrm{C}$ yr BP) has lower values of CIA and intermediate trace element concentrations. Zone I ( $c a$. 3,300 ${ }^{14} \mathrm{C}$ yr BPpresent day) is characterised by lower values of $\mathrm{SiO}_{2} /$ $\mathrm{Al}_{2} \mathrm{O}_{3}$ and highest $\mathrm{C}_{\text {org }}, \mathrm{CIA}$ and $\mathrm{TiO}_{2} / \mathrm{Al}_{2} \mathrm{O}_{3}$.

\section{Discussion}

The chemo-stratigraphic record at Lake Tecocomulco indicates presence of three different tephra layers. The tephra of $c a .50,000{ }^{14} \mathrm{C} \mathrm{yr} \mathrm{BP}$ (Tr III) is $c a .200 \mathrm{~cm}$ thick in both T-A and T-B cores (Caballero et al., 1999) and rhyolitic in composition. The geological studies of LópezHernández and Castillo-Hernández (1997) and GarcíaPalomo et al. (2002) suggest that the Acoculco volcano and its rhyolitic flow and surge deposits are present at a distance of $c a .8 \mathrm{~km}$ north-east of the lake basin. The comparable chemical compositions between Tr III and the Acoculco volcanic deposits (Fig. 4 and Table 2) suggest that the tephra of $c a .50,000{ }^{14} \mathrm{C}$ yr BP could be the result of a Plinian eruption event at the Acoculco volcano.

The tephra layers of ca. 31,000 ${ }^{14} \mathrm{C}$ yr BP (Tr II) and ca. $29,000{ }^{14} \mathrm{C}$ yr BP (Tr I) are ca. $10 \mathrm{~cm}$ and $5 \mathrm{~cm}$ thick in T-A95 core respectively and dacite to rhyolitic in nature. Apart from the T-A95 core, Tr II is also identified in the adjacent T-A and T-B cores (Caballero et al., 1999). However, Tr I is only present at T-A95 site (Fig. 2). The T-A95 site is located at a more marginal location than both T-A and T-B, so it is possible that Tr I is actually the reworked material from the $c a .31,000{ }^{14} \mathrm{C}$ yr BP volcanic activity. The relatively higher $\mathrm{Ba}$ and lower $\mathrm{Rb}$ and $\mathrm{Pb}$ concentrations in Tr I compared to Tr II suggests mixing of sediments derived from catchment volcanic rocks and tephra material. The geochemical data of lacustrine sediments from zone VI shows higher $\mathrm{Ba}$ and lower $\mathrm{Rb}$ and $\mathrm{Pb}$ contents compared to Tr II (Table 3 ). The association of minerals in Tr I shows similarity with clastic lake sediments and supports the earlier mentioned interpretation.

Recently, Rueda et al. (2006) reported that a Plinian eruption at $c a \cdot 31,490{ }^{14} \mathrm{C}$ yr BP of the Tláloc volcano (Fig. 1) distributed multilayered dacite-rhyolite white pumice to the north and north-east of the volcano and deposited $c a .100 \mathrm{~cm}$ of pumice at a distance of $12 \mathrm{~km}$ from the volcano. The chemical composition of both $\mathrm{Tr}$ II and Tr I are comparable to the Tláloc tephra (Table 2 and Fig. 4). Considering that the lake is located at a distance of $c a .60 \mathrm{~km}$ to the north-east of the Tláloc (Fig. 1), we assume that the Plinian eruption at Tláloc deposited the $\operatorname{Tr}$ II tephra layer at the southern margin of Tecocomulco. However, geochemical analysis of individual glass shards would be needed to confirm if both Tr II and Tr I are representative of two distinct Plinian events. Except the felsic tephra layers, lacustrine sediments of the sediment sequence were derived from mafic catchment rocks comprising of basaltic-andesites and andesites. This is suggested by higher abundance of $\mathrm{TiO}_{2}, \mathrm{Fe}_{2} \mathrm{O}_{3}, \mathrm{Cr}, \mathrm{Ni}, \mathrm{Cu}, \mathrm{Zn}$, presence of plagioclases and amphiboles.

For the Late Pleistocene-Holocene geochemical history of the lake basin, we compared the sediment stratigraphy (Fig. 2) with the geochemical zones (Fig. 5) that reflect different environments of deposition. Comparison with regional registers and complementary proxies (element ratios, mineralogy and sediment characteristics) are taken into consideration for the correct interpretation of the geochemical proxies. The chronological control of the geochemical zones is based on the four ${ }^{14} \mathrm{C}$ dates from the adjacent cores (T-A and T-B) and on geochemical analysis that allows the correlation of $\mathrm{Tr}$ II in T-A95 with the $31,000{ }^{14} \mathrm{C}$ yr BP tepha in the T-A and $\mathrm{T}$-B cores. Therefore, the paleohydrological changes identified in this work are not of high resolution, but they do give valuable paleoenvironmental information on a broader scale.

Zone VI (stratigraphic units IIIb and IIIa, 255-130 cm, ca. 31,000-25,700 ${ }^{14} \mathrm{C}$ yr BP) is characterized by high concentrations of $\mathrm{Cu}, \mathrm{Zn}, \mathrm{Rb}, \mathrm{Y}, \mathrm{Al}_{2} \mathrm{O}_{3}$ and $\mathrm{Fe}_{2} \mathrm{O}_{3}$ and indicates a period of relatively higher chemical weathering (average CIA $=70$ ) and more rapid soil formation in the lake catchment. However, the interaction between sediment and lake water was low during the deposition of tephra materials in the lake basin at ca.31,000 and $c a$. $29,000{ }^{14} \mathrm{C}$ yr BP which led to lower CIA values (57 and 60 , respectively). The relatively higher CIA (Fig. 3), presence of halloysite and absence of easily weatherable amphiboles (Table 1) indicates that the chemical weathering was higher between depths of 235 and $215 \mathrm{~cm}$ (stratigraphic unit IIIb, ca. 30,000-29,000 ${ }^{14} \mathrm{C}$ yr BP). Between ca. 28,000-25,700 ${ }^{14} \mathrm{C}$ yr BP $(175-130 \mathrm{~cm}$, stratigraphic unit IIIa), lower CIA and presence of amphiboles in the sediments suggest that the sedimentwater interaction reduced in the lake basin. The geochemical interpretation of zone VI is consistent with the diatom record of core $\mathrm{T}-\mathrm{B}$, which indicates a transition from a deeper environment prior to $c a$. 31,000 yr BP, 
dominated by planktonic Stephanodiscus spp., to a shallower lake, dominated by tychoplanktonic Fragillaria s.l. spp. between $31,000-25,700{ }^{14} \mathrm{C}$ yr BP (Caballero et al., 1999). Lake Chalco was also a relatively deep lake prior to $c a .30,000{ }^{14} \mathrm{C}$ yr BP, with a lowering lake level trend afterwards (Caballero and Ortega-Guerrero, 1998). This suggests that during the MIS 3 the lakes in the basin of Mexico were deeper but with a trend to reducing lake levels by the end of this period ( $c a .30,000$ to $25,000{ }^{14} \mathrm{C}$ yr BP).

Zone V (base of stratigraphic unit II, 130-118 cm, $c a$. $25,700{ }^{14} \mathrm{C}$ yr BP) consists of a calcite rich layer with high $\mathrm{Sr} / \mathrm{Rb}$ values which indicate that the southern margin of Lake Tecocomulco dried for some time. During this arid condition, the processes of chemical weathering and soil formation in the drainage basin were impeded, resulting in lower values of chemical index of alteration (average CIA $=40$ ), lower clastic input and metals in the sediments (Fig. 5 and Table 3). The absence of diatom preservation suggests very low lake levels after 25,700 ${ }^{14} \mathrm{C}$ yr BP and supports this interpretation. The paleolimnological record from the Lake Chalco also indicates a gradual lowering of the lake from $\mathrm{ca}$. 30,000 to 22,000 ${ }^{14} \mathrm{C}$ yr BP (Cabellero and Ortega-Guerrero, 1998).

Zone IV (middle of stratigraphic unit II, $118-70 \mathrm{~cm}$, ca. $25,700-16,300{ }^{14} \mathrm{C}$ yr BP) shows the presence of halloysite (Table 1), higher metal contents and lower Sr/ $\mathrm{Rb}$ (Table 3) indicative of a relatively humid regime if compared with zone V. This is supported by intermediate value of index of chemical weathering (average CIA = 68) and presence of coarser sediments (gravel) at T-A95 core site. Diatoms are absent in the sediments of this age indicating low or intermittent lake level, but pollen preservation in one sample is indicative of less arid conditions (Caballero et al., 1999), in agreement with the geochemical data. The pollen data from Tecocomulco, Texcoco and Chalco as well as from nearby Lake Chignahuapan of Upper Lerma basin (Fig. 1) are indicative of extensive grasslands with the presence of open woodlands which are associated to drier and colder climates at the beginning of the last glacial (Lozano-García et al., 1993; Lozano-García and Ortega-Guerrero, 1998; Caballero et al., 1999; Lozano-García et al., 2005), between $25,000-15,000{ }^{14} \mathrm{C}$ yr BP (early MIS 2). Cold climates during $24,000-17,000{ }^{14} \mathrm{C}$ yr BP (6 to $7{ }^{\circ} \mathrm{C}$ lower than today) are evident from the glacial advances in nearby (Fig. 1) Malinche, Iztaccihuatl and Nevado de Toluca volcanoes (Vázquez-Selem and Heine, 2004; Lachniet and Vázquez-Selem, 2005).

Zone III (top of stratigraphic unit II, 70-50cm, $c a$. $16,300{ }^{14} \mathrm{C}$ yr BP) is another calcium rich layer with no pollen or diatom preservation, all indicative of a return to arid conditions. This layer has higher $\mathrm{Zr} / \mathrm{Al}_{2} \mathrm{O}_{3}$ (Fig. 5) suggesting possible aeolian activity in the lake sur- roundings. The presence of $\mathrm{Mg}$-bearing calcite in zone III compared to zone $\mathrm{V}$ and indicates that lake salinity and regional aridity was higher at $c a .16,300{ }^{14} \mathrm{C}$ yr BP compared to $c a .25,700{ }^{14} \mathrm{C}$ yr BP. The arid conditions at zone III ( $c a$. $16,300{ }^{14} \mathrm{C}$ yr BP) correlate with a significant decrease in the grasslands and increase in the arboreal vegetation after $c a .16,000{ }^{14} \mathrm{C}$ yr BP in the pollen record from Lake Chignahuapan (Upper Lerma Basin), which has been interpreted as the beginning of a trend towards warmer climates (Lozano-García et al., 2005). This same pattern is also evident at a slightly later date (ca. 15,000 $14 \mathrm{yr} \mathrm{BP}$ ) in the pollen record from lake Chalco (Lozano-García and Ortega-Guerrero, 1998).

Zone II (stratigraphic unit Ib, 50-35 cm, ca. 16,3003,300 ${ }^{14} \mathrm{C}$ yr BP) shows higher $\mathrm{TiO}_{2} / \mathrm{Al}_{2} \mathrm{O}_{3}$ suggesting increasing mafic contribution to lake sediments compared to zones III, IV, V and VI. The lower CIA (average CIA = 59), relatively higher $\mathrm{CO}_{3}$ and $\mathrm{Sr} / \mathrm{Rb}$ (Table 3) indicate lower chemical weathering and evaporative conditions. Similarly, the lower abundance of metals suggests lower inflow into the basin. This unit is poorly represented in the previously studied cores (T-B and T-A), from which a sediment hiatus covering the Late Pleistocene to Holocene transitions was inferred. However, the particularly low apparent sedimentation rate $\left(13,000{ }^{14} \mathrm{C}\right.$ yrs in $\left.25 \mathrm{~cm}\right)$ of this unit still suggests that there is a hiatus either at the base (ca. $16,300{ }^{14} \mathrm{C} \mathrm{yr} \mathrm{BP}$ ) or the top of the unit ( $c a$. $3,300{ }^{14} \mathrm{C}$ yr BP). This hiatus is comparable to the hiatus recorded in Texcoco between ca. $14,400-6000{ }^{14} \mathrm{C}$ yr BP (Bradbury, 1989; Lozano-García and Ortega-Guerrero, 1998). The Chalco data suggest increasing temperature with decreasing grasslands and presence of denser forests after $c a$. $15,000{ }^{14} \mathrm{C}$ yr BP (Lozano-García and Ortega-Guerrero, 1998) and a stable to slightly higher water level by the end of the last glaciation (late MIS 2, ca. $15,000-10,000{ }^{14} \mathrm{C}$ yr BP) (Caballero and OrtegaGuerrero, 1998). In the higher elevations of the basin of Mexico, there are registers of minor glacial advances between 17,000 and $11,600{ }^{14} \mathrm{C}$ yr BP and again during $c a$. 10,000-8,500 ${ }^{14} \mathrm{C}$ yr BP (D’Antoni, 1993; Vázquez-Selem and Heine, 2004; Lachniet and Vázquez-Selem, 2005). In the Tláloc (3100 m), D’Antoni (1993) estimated temperature of $2-3.5^{\circ} \mathrm{C}$ lower than present during early Holocene. Similarly, Lozano-García and Vázquez-Salem (2005) reported glacier advances at Iztaccíhuatl volcano (3860 $\mathrm{m}$ ) and $\mathrm{ca} .3-4^{\circ} \mathrm{C}$ colder temperature than present. In Lake Chalco, the early Holocene $\left(10,000\right.$ to $5,000{ }^{14} \mathrm{C}$ yr BP) is however marked by a transition to a shallow saline lake, suggestive of an arid phase that is also recorded in nearby Lake Chignahuapan (Caballero et al., 2002). Therefore, it is likely that the sediment hiatus at Tecocomulco is constrained to the early Holocene rather than to the Late Pleistocene.

Zone I (stratigraphic unit Ia, 35-0 cm, 3,300-0 ${ }^{14} \mathrm{C}$ yr 
$\mathrm{BP})$ has highest values of CIA $(=74)$ and $\mathrm{C}_{\text {org }}(=1.18 \%)$ and value of $\mathrm{TiO}_{2} / \mathrm{Al}_{2} \mathrm{O}_{3}$ is similar to zone II. The gradually increasing CIA values, presence of halloysite (Table 1) and metals contents (Table 3 and Fig. 5) suggest that chemical weathering was relatively higher during the deposition of zone I ( $c a .3,300{ }^{14} \mathrm{C}$ yr BP-present day) compared to zone II ( $c a \cdot 16,300-3,300{ }^{14} \mathrm{C}$ yr BP). In the last $3,300{ }^{14} \mathrm{C}$ yr BP (zone I), preservation of $\mathrm{C}_{\text {org }}$ indicates higher organic productivity compared to the rest of the zones in the lake basin. The records from Texcoco and Chalco are consistent with the trend in Tecocomulco of a slight increase in water level by the Late Holocene $\left(<c a .5,000{ }^{14} \mathrm{C}\right.$ yr BP) compared to the early and mid Holocene.

\section{SUMMARY}

The geochemical and mineralogical characteristics of the Late Pleistocene-Holocene sediments from the Lake Tecocomulco indicate fluctuating paleoenvironmental and paleohydrological conditions in the north-eastern Basin of Mexico. More specifically:

1. The lacustrine sediments register two events of volcanic eruptions in the last $50,000{ }^{14} \mathrm{C}$ yr BP. The rhyolitic eruption at $c a .50,000{ }^{14} \mathrm{C}$ yr BP could be from the Acoculco volcano and the proximity of the volcano and lake basin might have favored the deposition of $c a$. $200 \mathrm{~cm}$ of tephra in the southern margin of the lake. The tephra of $c a .31,000{ }^{14} \mathrm{C}$ yr BP is dacitic-rhyolitic and related to the Tláloc volcano.

2. The integrated data from Tecocomulco and Chalco suggest that MIS 3 was characterized by deeper lakes but with a trend to lowering available moisture by the end of this interval, after $c a .28,000{ }^{14} \mathrm{C}$ yr BP.

3 . Two particularly arid events during the last glaciation (MIS 2) are identified, ca. 25,700 ${ }^{14} \mathrm{C}$ yr BP and ca. $16,300{ }^{14} \mathrm{C}$ yr BP, which are broadly correlationable with glacial advances. The $c a .16,300{ }^{14} \mathrm{C}$ yr BP arid event seems to correlate with the beginning of a warming trend that leads to the Holocene transition.

4. Cores T-A and T-B showed a sedimentation huiatus between ca. $16,300-3,300{ }^{14} \mathrm{C}$ yr BP (Caballero et al., 1999); the profile at T-A95 has deposition of $25 \mathrm{~cm}$ of sediments showing low CIA indicating lower chemical weathering and humidity. Correlation of the data from Tecocomulco with those from Texcoco, Chalco and Chignahuapan suggest that the hiatus can be related to multiple episodes of lower precipitation and lake levels during early to mid Holocene, causing erosion of the sediment profile at the lake margin.

5. Presence of halloysite, higher CIA and $\mathrm{C}_{\text {org }}$ in the lake sediments suggest a recovery in lake level at Tecocomulco during the last $3,000{ }^{14} \mathrm{C}$ yr BP, a similar trend also recorded at Texcoco and Chalco, suggesting slightly more humid climatic conditions in the late Holocene.

Acknowledgments-PDR acknowledges the financial support from the projects of PROMEP (PROMEP/103.5/05/1919) and Instituto de Geofísica, UNAM (POS 4). Technical supports from Elizabeth Hernández and Santiago are thankfully acknowledged. Authors are thankful to Dr. Sarah Davies and an anonymous reviewer for their suggestions and critical comments.

\section{REFERENCES}

Alatriste-Vilchis, D., Campos-Enríquez, J. O., Huizar-Alravez, R. and Marínez-Campos, R. (2005) La estructura subsuperficial de la subcuenca de Tecocomulco. La Laguna de Tecocomulco geo-ecologia de un desastre (Guisar-Alvarez, R., Jiménez Fernández, E. J. and Juárez-López, C., eds.), 33-48, Special Publication 3, Instituto de Geología, Universidad Nacional Autónoma de Mexico (in Spanish).

Andersson, P. O. D., Worden, R. H., Hodgson, D. M. and Flint, S. (2004) Provenance evolution and chemostratigraphy of a Paleozoic submarine fan-complex: Tanqua Karoo Basin, South Africa. Mar. Petrol. Geol. 21, 555-577.

Bradbury, J. P. (1971) Paleolimnology of Lake of Texcoco Mexico: Evidence from diatoms. Limnol. Oceanogr. 16, 180-200.

Bradbury, J. P. (1989) Late Quaternary lacustrine paleoenvironments in the Cuenca de Mexico. Quat. Sci.Rev. 8, 75-100.

Caballero, M. M. (1997) The last glacial maximum in the basin of Mexico: the diatom record between 34,000 and 15,000 years BP from Lake Chalco. Quat. Int. 43/44, 125-136.

Caballero, M. M. and Ortega-Guerrero, B. (1998) Lake levels since 40,000 years ago at Chalco Lake, near Mexico City. Quat. Res. 50, 90-106.

Caballero, M., Lozano, S., Ortega, B., Urrutia, J. and Macias, J. L. (1999) Environmental characteristics of Lake Tecocomulco, northern basin of Mexico, for the last 50,000 years. J. Paleolimnol. 22, 399-411.

Caballero, M. M., Ortega, B., Valadéz, F., Metcalfe, S., Macías, J. L. and Sugiura, Y. (2002) Sta. Cruz Atízapán: a 22-ka lake level record and climatic implications for the late Holocene human occupation in the upper Lerma basin, central Mexico. Palaeogeogr., Palaeoclimatol., Palaeoecol. 186, 217-235.

Cardoso, M. D. and García, E. (1982) Vegetation and climate in the basin of Mexico. Latin American Regional Conference IGU, Brazil, 1982: Geographical Tropics of Mexico City and Its Environments, 19-24, Instituto de Geografia, Universidad Nacional Autónoma de Mexico.

D’Antoni, H. L. (1993) Paleotemperatures of La Malinche: a palynological hypothesis. Grana 32, 354-358.

Douglas, M. W., Maddox, R. A., Howard, K. and Reyes, S. (1993) The Mexican Monsoon. J. Climate 6, 1665-1677.

Enzel, Y., Ely, L. L., Mishra, S., Ramesh, R., Amit, R., Lazar, B., Rajguru, S. N., Baker, V. R. and Sandler, A. (1999) High resolution Holocene environmental changes in the Thar Desert, northwestern India. Science 284, 125-128. 
Fedo, C. M., Nesbitt, H. W. and Young, G. M. (1995) Unraveling the effects of potassium metasomatism in sedimentary rocks and paleosols, with implications for paleoweathering conditions and provenance. Geology 23, 921-924.

García, E. (1966) Los climas del Valle de México según el sistema de clasificación climática de Koeppen modificando por la autora. Conferencia Regional Latinoamericana IGU: Simposio sobre el Valle y la ciudad de México, 27-48, Sociedad Mexicana de Geografia y Estadística, México (in Spanish).

García-Palomo, A. and Macías, J. L. (2000) Estratigrafia Volcanica de la región de Apan, Hidalgo (abstract). GEOS 20(3), 309.

García-Palomo, A., Macías, J. L., Tolson, G., Valdez, G. and Mora-Chaparro, J. C. (2002) Volcanic stratigraphy and geological evolution of the Apan region, east-central sector of the Trans-Mexican Volcanic Belt. Geofisica Internacional 41, 133-150.

Hardie, L. A., Smoot, J. P. and Eugster, H. P. (1978) Saline lakes and their deposits: a sedimentological approach. Modern and Ancient Lake Sediments (Matter, A. and Tucker, M., eds.), 7-11, International Association of Sedimentologists, Special Publication 2.

Haug, G. H., Gunther, D., Peterson, L. C., Sigman, D. M., Hughen, K. A. and Aeschlimann, B. (2003) Climate and the collapse of Maya civilization. Science 299, 1731-1735.

Huizar-Alvarez, R., Mitre-Salazar, L. M., Méndez-García, T., Juárez, S. F. and Kumiko-Simhada, M. (2005) Caracterización hidrogeológica de la subcuenca de Tecocomulco. La Laguna de Tecocomulco geo-ecologia de un desastre (Guisar-Alvarez, R., Jiménez Fernández, E. J. and Juárez-López, C., eds.), 89-109, Special Publication 3, Instituto de Geología, Universidad Nacional Autónoma de México (in Spanish).

Lachniet, M. S. and Vázquez-Selem, L. (2005) Last Glacial Maximum equilibrium line altitudes in the circumCaribbean (Mexico, Guatamala, Costa Rica, Colombia and Venezuela). Quat. Int. 138-139, 129-144.

Le Maitre, R. W., Bateman, P., Dudek, A., Keller, J., Lameyre Le Bas, M. J., Sabine, P. A., Schmid, R., Sorenson, H., Streckeisen, A., Woolley, A. R. and Zanettin, B. (1989) A Classification of Igneous Rocks and Glossary of Terms. Blackwell, Oxford.

López-Hernández, A. and Castillo-Hernández, D. (1997) Exploratory drilling at Acoculco, Puebla, Mexico: A hydrothermal system with only non-thermal manifestation. Geotherm. Resour. Council Trans. 21, 429-433.

Lozano, R. and Bernal, J. P. (2005) Characterization of a new set of eight geochemical reference material for XRF major and trace element analysis. Revista Mexicana de Ciencias Geológicas 22, 329-344.

Lozano-García, M. S. and Ortega-Guerrero, B. (1998) Late Quaternary environmental changes of the central part of the Basin of Mexico: Correlation between Texcoco and Chalco basins. Rev. Palaeobotany Palynol. 99, 77-93.

Lozano-García, M. S. and Vázquez-Selem, L. (2005) A highelevation Holocene pollen record from Iztaccíhuatl volcano, central Mexico. The Holocene 15, 329-338.

Lozano-García, M. S., Ortega-Guerrero, B., Caballero-Miranda,
M. and Urrutia-Fucugauchi, J. (1993) Late Pleistocene and Holocene Paleoenvironments of Chalco Lake, Central Mexico. Quat. Res. 40, 332-342.

Lozano-García, S., Sosa-Nájera, S., Sugiera, Y. and Caballero, M. (2005) 23,000 $\mathrm{yr}$ of vegetation histrory of the Upper Lerma, a tropical high-altitude basin in Central Mexico. Quat. Res. 64, 70-82.

Metcalfe, S. E. (1997) Palaeolimnological records of climate change in México-Frustrating past and Promising future? Quat. Int. 43/44, 111-116.

Mosiño-Aleman, P. A. and García, E. (1974) The climate of Mexico. Climates of North America, World Survey of Climatology (Brysn, H. and Hare, F. K., eds.), Vol. 11, 345405, Elsevier, New York.

Nesbitt, H. W. (1979) Mobility and fractionation of rare earth elements during weathering of a granodiorite. Nature 279, 206-210.

Nesbitt, H. W. and Young, G. M. (1982) Early Proterozoic climates and plate motions inferred from major element chemistry of lutites. Nature 299, 715-717.

Nesbitt, H. W. and Young, G. M. (1984) Prediction of some weathering trends of plutonic and volcanic rocks based on thermodynamic and kinetic considerations. Geochim. Cosmochim. Acta 48, 1523-1534.

Norrish, K. and Pickering, J. G. (1983) Clay Minerals, an Australian Viewpoint. Academic Press, London.

Pye, K. and Krinsley, D. H. (1986) Diagenetic carbonate and evaporite minerals in Rotliegend aeolian sandstones of the southern North Sea: their nature and relationship to secondary porosity. Clay Mineral. 21, 443-457.

Rosen, M. R. (1994) The importance of groundwater in playas: a review of playa classification and the sedimentology and hydrology of playas. Paleoclimate and Basin Evolution of Playa Systems (Rosen, M. R., ed.), 1-18, Geological Society of America, Special Paper 289.

Roy, P. D., Smykatz-Kloss, W. and Sinha, R. (2006) Late Holocene geochemical history inferred from Sambhar and Didwana playa sediments, Thar Desert: comparison and synthesis. Quat. Int. 144(1), 84-98.

Roy, P. D., Nagar, Y. C., Juyal, N., Smykatz-Kloss, W. and Singhvi, A. K. (2008) Geochemical signatures of Late Holocene paleo-hydrological changes from Phulera and Pokharan saline playas near the eastern and western margins of the Thar Desert, India. J. Asian Earth Sci. (doi:10.1016/j.jseaes.2008.05.006) (in press).

Rueda, H., Arce, J., Macias, J. and García-Palomo, A. (2006) A $\sim 31$ ka Plinian-subplinian eruption at Tláloc Volcano, Sierra Nevada, Mexico (abstract). Eos Trans. AGU 87(52), Fall Meet. Suppl.

Schuett, B. (1998) Reconstruction of palaeoenvironmental conditions by investigation of Holocene playa sediments in the Ebro Basin, Spain: preliminary results. Geomorphology 23, 273-283.

Schuett, B. (2000) Holocene palaeohydrology of playa lakes in northern and central Spain: a reconstruction based on the mineral composition of lacustrine sediments. Quat. Int. 73/ 74, 7-27.

Shaw, P. A. and Thomas, D. S. G. (1997) Pans, playas and salt lakes. Arid Zone Geomorphology: Process, Form and 
Change in Drylands (Thomas, D. S. G., ed.), 293-318, John Wiley \& Sons, New York.

Sinha, R., Smykatz-Kloss, W., Stüben, D., Harrison, S. P., Berner, Z. and Kramar, U. (2006) Late Quaternary palaeoclimatic reconstruction from the lacustrine sediments of the Sambhar playa core, Thar Desert margin, India. Palaeogeogr., Palaeoclimatol., Palaeoecol. 233, 252-270.

Taylor, S. R. and McLennan, S. H. (1985) The Continental Crust: Its Composition and Evolution. Blackwell Scientific Publications, Oxford, London.

Vázquez-Selem, L. and Heine, K. (2004) Late Quaternary glaciation of Mexico. Quaternary Glaciations-Extent and
Chronology, Part III (Ehlers, J. and Gibbard, P. L., eds.), 233-242, Elsevier, South America.

Verma, S. P., Lozano Santa Cruz, R., Girón, P. and Velasco, F. (1996) Calibración preliminar de Fluorescencia de Rayos $\mathrm{X}$ para análisis cuantitativo de elementos trazas en rocas ígneas. Actas INAGEQ 2, 231-242 (in Spanish).

Visser, J. N. J. and Young, G. M. (1990) Major element geochemistry and paleoclimatology of the PermoCarboniferous glaciogenic Dwyka Formation and postglacial mud rocks in Southern Africa. Palaeogeogr., Palaeoclimatol., Palaeoecol. 81, 49-57. 